\title{
Soluble Interleukin 2 Receptor Measurement
}

National Cancer Institute

\section{Source}

National Cancer Institute. Soluble Interleukin 2 Receptor Measurement. NCI Thesaurus.

Code C158220.

The determination of the amount of soluble interleukin 2 receptor present in a sample. 